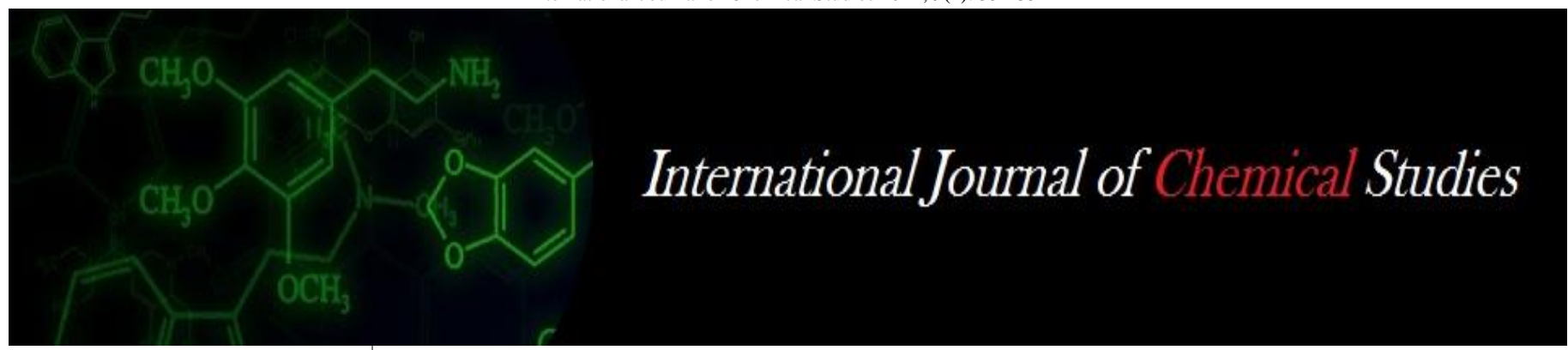

P-ISSN: 2349-8528

E-ISSN: 2321-4902

www.chemijournal.com

IJCS 2021; 9(1): 351-354

(C) 2021 IJCS

Received: 29-10-2020

Accepted: 10-12-2020

\section{Purabi Kaushik}

Department of ILFC (AGB),

College of Veterinary Science,

Assam Agricultural University,

Khanapara, Guwahati, Assam,

India

\section{Jnyanashree Saikia}

Department of ILFC (AGB),

College of Veterinary Science,

Assam Agricultural University,

Khanapara, Guwahati, Assam,

India

\section{Kabitabala Kalita}

Department of Animal

Biotechnology, College of

Veterinary Science, Assam

Agricultural University,

Khanapara, Guwahati, Assam,

India

\section{Rajjyoti Deka}

Department of Livestock

Production and Management,

College of Veterinary Science,

Assam Agricultural University, Khanapara, Guwahati, Assam, India

\section{Morphology and morphometry characteristics of Pati duck}

\author{
Purabi Kaushik, Jnyanashree Saikia, Kabitabala Kalita and Rajjyoti \\ Deka
}

DOI: https://doi.org/10.22271/chemi.2021.v9.i1e.11253

\begin{abstract}
Pati ducks are recently registered indigenous non-descript duck variety of Assam mainly used for meat, egg and ritual sacrifices. In the present study, some important phenotypic and morphometric traits were studied under field conditions. Morphometric measurement for both Drake and Ducks were recorded and plumage colour patterns of all body parts were noted by visual observation. The mean length $(\mathrm{cm})$ for Body, Shank, Bill, Neck, Head, Breast, Wing span and body circumference of Dracks were recorded as $61.40 \pm 1.17,5.54 \pm 0.11,3.26 \pm 0.25,15.56 \pm 0.37,7.79 \pm 0.14,14.90 \pm 0.45,84.33 \pm 0.90,40.57 \pm 1.06$ and Ducks were $60.73 \pm 0.69,4.78 \pm 0.07,5.12 \pm 0.09,16.01 \pm 0.16,7.38 \pm 0.10,13.28 \pm 0.15,78.55 \pm 0.53$, $37.41 \pm 0.44$ respectively. The major colour pattern of bill, shank and feet was found to be yellow, whereas skin was mostly white in colour and plumage colour pattern found to be white, black and brown in different parts of the body. The blue type plumage colour was also found somewhere in head region.
\end{abstract}

Keywords: Morphometry, Pati duck, phenotypic traits

\section{Introduction}

The favourable climatic condition and fertile land resources of Assam plays a significant role for agricultural and livestock production in the region. Duck farming is a major component in integrated farming system and plays a significant role in women empowerment and upliftment of socio-economic status of the farming community of Assam. Due to hot-humid climatic condition of Assam along with extensive availability of resources like ponds, river, marshy wet lands etc. provides a suitable natural habitats for duck rearing in rural areas of the states. Duck eggs and meats are widely accepted by different sections of the society and plays a vital role to fulfil nutritional security. The peopleof Assam are mostly shown their keen interested in duck husbandry to meet their demands for meat and egg as a source for animal protein. The state has a7.33 lakhs Duck population and stands second position in India. Out of the total duck population reared in Assam, available duck breeds are Pati, Nageswari, Chara Chambeli, Khaki Campbell and White Pekin. Pati duck is the most commonly reared by rural people of Assam and it was recognized by the National Burea of Animal Genetic Resources in the year 2017. Their age at sexual maturity is in between 220-235 days and age at first egg laying is on an average of 240 days. They have an average egg weight of $60.5 \mathrm{~g}$ and egg production ranging from 75-90 eggs per annum. (Kalita et.al. 2009; Mahanta J.D., 2009). Though, many phenotypic studies have been done on Pati duck, but scany informations are found in morphology and morphometrical characteristics. Hence, the present study is undertaken to identify the morphology and morphometrical characteristics of Pati duck.

\section{Materials and Methods}

The present study was based on field survey conducted in Nalbari and Mangaldoi district of Assam. The farmers reared duck mainly in a backyard system using locally available materials for housing, and maintained average flock size of 8-10 birds. Ducks were mainly fed with left over kitchen waste, Rice bran, broken Maize etc. A questionnaire was prepared covering all the information related to phenotypic characteristics, morphology and morphometry of duck and others duck husbandry practices covering 46 adult birds (20 weeks).

Some important phenotypic characteristics viz. Bill length and width, Head length and width, Neck length, Breast length, Body length, Wing Span, Body Circumference, Shank length were
Corresponding Author: Purabi Kaushik Department of ILFC (AGB) College of Veterinary Science, Assam Agricultural University, Khanapara, Guwahati, Assam, India 
measured by a standard measuring tape calibrated in centimeters. A separate sheet was prepared mentioning different colours related to shank, skin and feet. The birds were closely observed for distribution of colour pattern in Bill, Eye and Eyelid. Plumage colour pattern in all part of the body (Head, Neck, Wing, Back, Tail, Thigh and Breast) were identified and documented by visual observation for the present study. All the data are subjected to statistical analysis by standard method and presented in Mean \pm S.E.

\section{Result and Discussion}

The result of morphological characteristics on Bill Colour was found to be mostly yellow (50\%) followed by Red (25\%) and Yellow Brown (12.5\%). The most common Eye colour was
Black $(50 \%)$ followed by Gray $(25 \%)$ and brown $(12.5 \%)$. The Eyelid colours were mostly (57.14\%) and Gray (28.57\%). The Shank colour observed mostly yellow (44.44\%) followed by white $(22.22 \%)$, black $(22.22 \%)$ and blue $(11.11 \%)$. The Skin was white $(50 \%)$, yellow $(25 \%)$ and blue $(25 \%)$ in colour. The Feet colour mainly observed was yellow (40\%) followed by black (20\%), blue (20\%) and white (10\%). All the morphological observations were for both Duck and Drake. Morphological variety has been shown in Fig.1. The morphometric characteristics of Pati duck of Assam were presented in Table.1. In the present study, distribution pattern of plumage colour in both duck and drake were depicted in Fig 2 and Fig 3.

Table 1: Morphometric characteristics of Pati ducks of Assam

\begin{tabular}{|c|c|c|}
\hline Traits & Duck $(\mathbf{n}=\mathbf{3 2})$ Mean \pm S.E & Drake (n=14) Mean \pm S.E \\
\hline Bill length & $5.12 \pm 0.09$ & $5.71 \pm 0.30$ \\
\hline Bill width & $3.74 \pm 0.11$ & $3.26 \pm 0.25$ \\
\hline Head length & $7.38 \pm 0.10$ & $7.79 \pm 0.14$ \\
\hline Head width & $3.21 \pm 0.10$ & $3.10 \pm 0.13$ \\
\hline Neck length & $16.01 \pm 0.16$ & $15.56 \pm 0.37$ \\
\hline Breast length & $13.28 \pm 0.15$ & $14.90 \pm 0.45$ \\
\hline Body length & $60.73 \pm 0.69$ & $61.40 \pm 1.17$ \\
\hline Wing span & $78.55 \pm 0.53$ & $84.33 \pm 0.90$ \\
\hline Body circumference & $37.41 \pm 0.44$ & $40.57 \pm 1.06$ \\
\hline Shank length & $4.78 \pm 0.07$ & $5.54 \pm 0.11$ \\
\hline
\end{tabular}
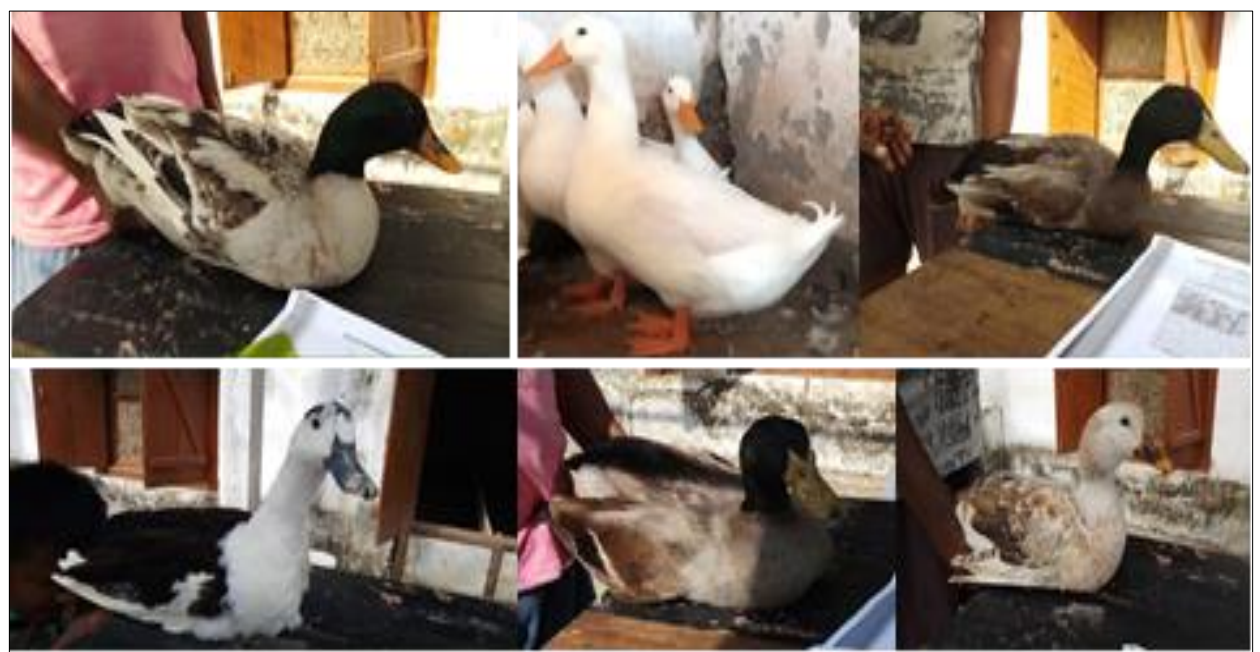

Fig 1: Different morphological variety in Pati Duck, Assam

The average Bill length was found to be $5.12 \pm 0.09 \mathrm{~cm}$ in Pati duck and 5.71 \pm 0.30 in drake. Similar finding was recorded by Arundhati et al., 2018 who reported the bill length of Pati duck was $5.44 \mathrm{~cm}$. Ajith et al. (2009) found significantly higher bill length $(6.70$ and $6.80 \mathrm{~cm})$ in males in comparison with respective females $(6.10,6.30 \mathrm{~cm})$ with regard to Chara and Chemballi ducks of Kerala. Yakubu (2009) ${ }^{[6]}$ reported shorter bill length of $4.98 \mathrm{~cm}$ and $3.75 \mathrm{~cm}$ for African Muscovy male and female ducks. Another finding was recorded by Murugan et al., $2009^{\text {[3] }}$ in Sanyasiand Keeri variety ducks of India; they recorded the bill length of $6.81 \pm$ 0.82 and $6.1 \pm 0.90 \mathrm{~cm}$ respectively for both the variety. Another observation on the Bill length of desi ducks in west Bengal was $5.25 \pm 0.04 \mathrm{~cm}$, reported by Vij et al., $2010^{[5]}$. Morduzzaman et al. (2015) [2] also reported bill length of Nageswari ducks of Bangladesh were $5.87 \pm 0.09$ and $5.54 \pm$ 0.07 in male and female respectively. The variation of bill length might be due to the difference in breed. In the present study, bill and head width were larger in Duck than Drake. These follows opposite to the result of desi duck of Odhisa(kamal et al., 2014),Desi duck of West Bengal (Vij et al. 2010) ${ }^{[5]}$ and Nageswari ducks (Morduzzaman et al. 2015) ${ }^{[2]}$, where the recorded a larger bill and head width of Drake than that of Duck.

In the present study average Neck length $(\mathrm{cm})$ recorded was more in duck $(16.01 \pm 0.16)$ than that of drake $(15.56 \pm 0.37)$. Yakubu (2009) ${ }^{[6]}$ also recorded the mean neck length for male and female African Muscovy ducks as $18.10 \mathrm{~cm}$ and $14.33 \mathrm{~cm}$ respectively, while Murugan et al. (2009) [3] recorded a higher value for the neck length of $21.10 \pm 0.12$ $\mathrm{cm}$ and $18.70 \pm 0.24 \mathrm{~cm}$ for Sanyasi Drake and Ducks respectively. The difference in neck length might be due to the breed difference. 


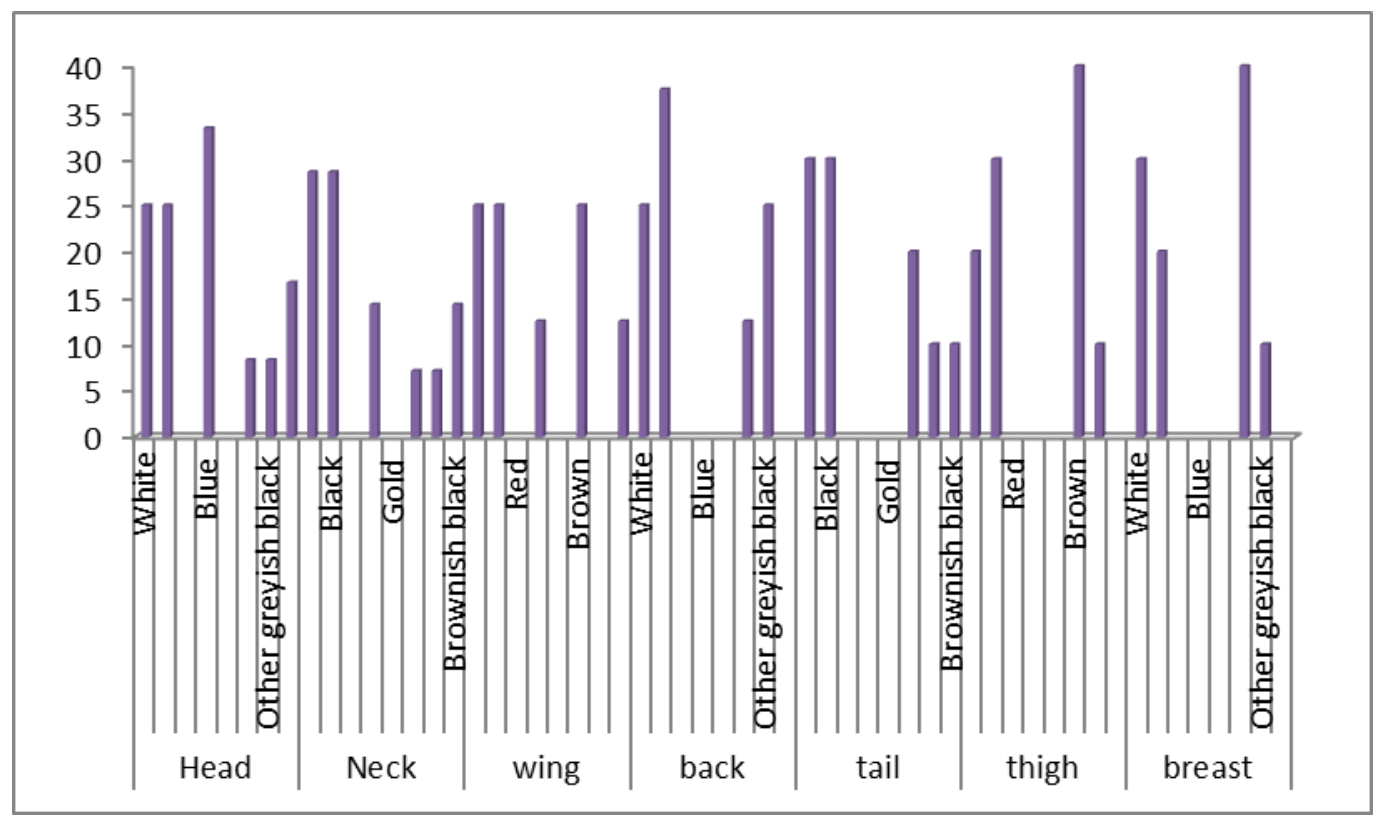

Fig 2: Plumage colour pattern of Drake

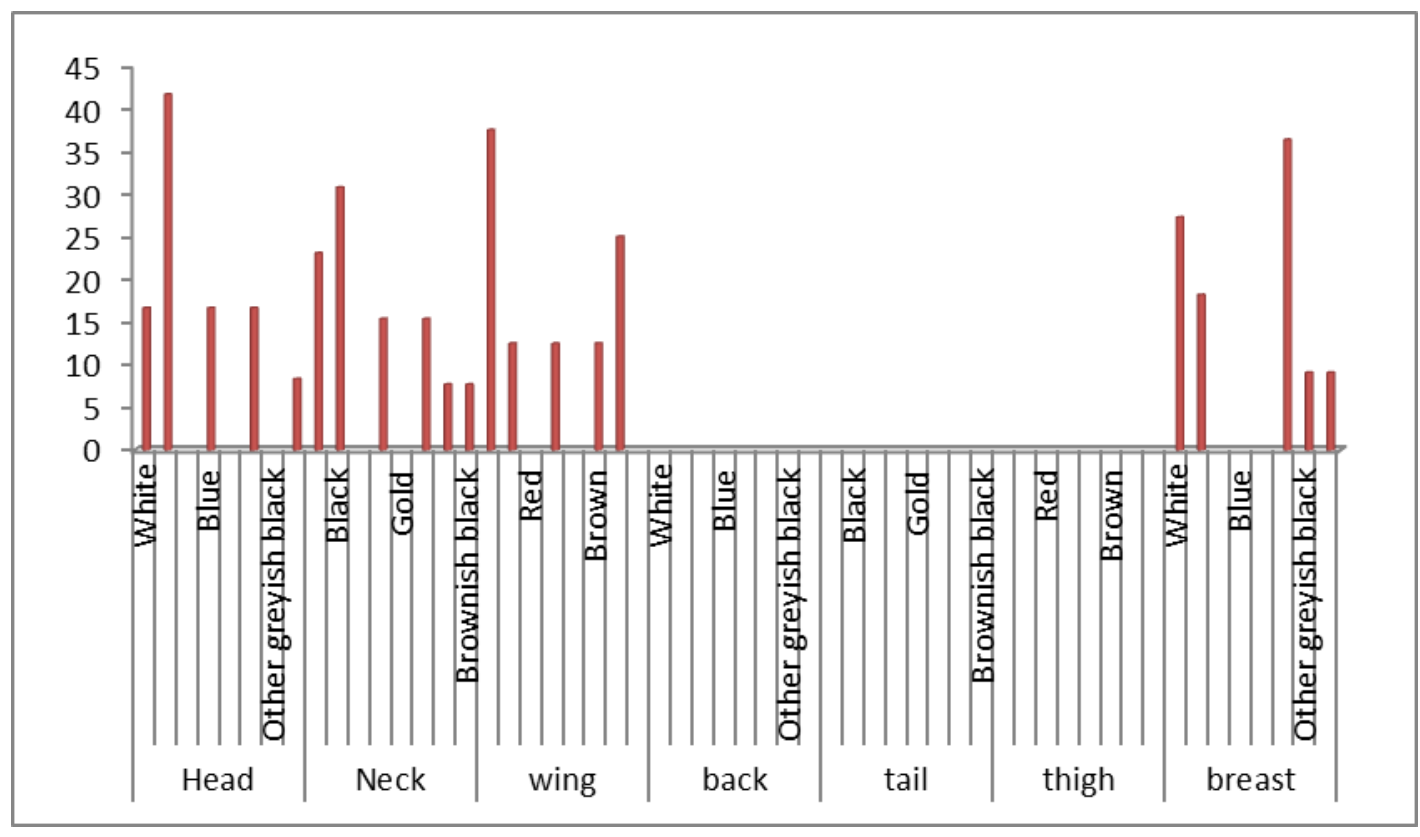

Fig 3: Plumage colour pattern of Duck

In the present observation, shank length of Pati duck was recorded as $4.78 \pm 0.07 \mathrm{cmand}$ drake is $5.54 \pm 0.11 \mathrm{~cm}$. Earlier Arundhati et al., 2018 reported shank length of $5.675 \mathrm{~cm}$ for Pati Duck. Zaman et al. (2007) ${ }^{[7]}$ also recorded the mean shank length of male and female as $6.67 \pm 0.71$ and $6.12 \pm 0.68$ $\mathrm{cm}$ respectively for Nageswari ducks of Assam. Another study by Kamal et al 2019, the average shank length was reported as $6.21 \mathrm{~cm}$ for Drakes and $5.89 \mathrm{~cm}$ for Ducks of Odisha. However, Sharma et al. 2003 reported the shank length for Nageswari duck were 6.49 cmat 20 weeks of age.Another report on shank length for Desi ducks of West Bengal was reported as $5.67 \mathrm{~cm}$ by Vij et al. $201{ }^{[5]}$. Veeramani et al., 2014 found Significantly higher shank length for males thanfemale ducks of both Sanyasi and Keeri varieties $(5.61 \pm 0.02 \mathrm{~cm}$ for males and $5.56 \pm 0.01 \mathrm{~cm}$ for females); Whereas, Renchi et al., (1979) recorded the meanshank length in male and female Desi ducks of Kerala at 12 weeks of age as $6.44 \pm 0.04 \mathrm{~cm}$ and $6.15 \pm 0.02 \mathrm{~cm}$ and reported that males had significantly higher shank length than female ducks and similar values were recorded by Ajith et al.
(2009) for Charaand Chemballiducks of Kerala. The difference in the shank length of different varieties of indigenous ducks might be attributed to the variation in the genotype and environment where they were reared.

In the present study average body length of male and female bird of Pati Ducks were recorded as $60.73 \pm 0.69 \mathrm{~cm}$ and61.40 \pm 1.17 cmrespectively. Murugan et al., 2009 [3], reported the body length for Sanyasiand Keerivarieties was $23.85 \pm 0.09 \mathrm{~cm}$ and $23.64 \pm 0.08 \mathrm{~cm}$ respectively. On the other hand, Yakubu (2009) ${ }^{[6]}$ recorded mean values of body length for male and female African Muscovy ducks as $47.86 \mathrm{~cm}$ and $38.35 \mathrm{~cm}$ respectively. The lower valued obtained in this study might be due to the variation in the size and conformation of the distinct variety / breed of ducks.

In the present study the Wing span found to be higher in Drake $(84.33 \pm 0.90 \mathrm{~cm})$ than that of Duck $(78.55 \pm 0.53 \mathrm{~cm})$. Average neck length was measured and was found to be greater in females than that of males. Opposite trend, but higher values of $(23.49 \pm 0.58 \mathrm{~cm}$ in males and $21.59 \pm 0.49 \mathrm{~cm}$ in females) were noted in Nageswari duck by Morduzzaman 
et al. $2015^{[2]}$ and lower value $(13.47 \pm 0.25$ and $12.90 \pm 0.22 \mathrm{~cm})$ Sanyasi and Keeri variety of ducks by Murugan et al. $2009^{[3]}$.

\section{Conclusion}

The present study will provide baseline information of morphology and morphometric characteristics of native Pati Duck breed of Assam. It will help to formulate the selection strategies and systematic breeding policy. The study also helps to exploiting potentiality of native ducks and conservation of unique germplasmfor near future.

\section{Acknowledgement}

The authors are thankful to the Department of Biotechnology, Govt. of India, New Delhi (Project ID 102/IFD/SAN/1335/2018-2019) for financial assistance to carry out the research work.

\section{References}

1. Ajit BB, Padwal NP, Anish D, Deepa GM, Peethambaran PA. Evaluation of bill length and shank length in kuttanad ducks of kerala.proceedings of the IV World Waterfowl Conference, Trisur, India 2009,173p.

2. Morduzzaman M, Bhuiyan AKFH, Rana M, Islam MR, Bhuiyan MSA. Phenotypic characterization and production potentials of Nageswari duck in Bangladesh. Bangladesh Journal of Animal Science 2015;44(2):92-99.

3. Murugan M, Gopinathan A, Sivakumar T. Indigenous duck varieties in Uthiramerur block of north eastern agroclimatic zone of Tamil Nadu. Proceedings of the IV World Waterfowl Conference, 2009,89-92p.

4. Phookan A, Das B, Das A, Islam R, Sharma M, Bharali $\mathrm{K}$ et al. Morphology, morphometry and certain egg quality traits of indigenous ducks of North Eastern region of India. International Journal of Chemical Studies 2018;6(2):3131-3133.

5. Vij PK, Tantia MS, Pan S, Vijh RK. Morphometric and egg characteristics of indigenous ducks. Journal of Livestock Biodiversity 2010;2(2):77-80.

6. Yakubu A. An assessment of sexual dimorphism in African Muscovy ducks (Cairina. moschata) using morphological measurements and discriminant analysis. Proceedings of the IV World Waterfowl Conference, 2009,69-75p.

7. Zaman G, Goswami RN, Aziz A, Nahardeka N, Mahanta JD. Studies on body weight andshank length of Nageswari duck of Assam. Indian Journal of Poultry Science 2007;42(1):79-80.

8. Zaman G, Goswami RN, Aziz A, Nahardeka N, Roy TC, Mahanta JD. Farming system of Nageswari ducks in North-Eastern India (Assam). World's Poultry Science Journal 2005;61:687-693. 